\title{
5
}

\section{International Interdependence and the Constraints on Macroeconomic Policies}

Jacob A. Frenkel

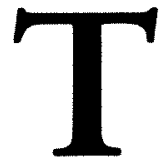

his chapter examines within a theoretical framework some of the constraints that the openness of the economy impose upon policy making. ${ }^{1}$ The open economy is linked to the rest of the world primarily through three key linkages: through international trade in goods and services, through international mobility of capital, and through international exchanges of national monies. Macroeconomic policies for open economies differ, in fundamentally important ways, from the corresponding policies for closed economies. The openness of the economy imposes constraints on the effectiveness and proper conduct of macroeconomic policies but it also provides policymakers with information that may be usefully exploited in the design of policy.

In order to set the stage for the analysis and in order to illustrate how the degree of integration in world capital markets impacts on the proper policy mix, my next section analyzes the famous "policy assignment problem." The main message of this analysis-which is carried out within the analytical framework of the Mundell-Fleming model of the 1960s vintage-is that from some points of view an increased degree of capital market integration may simplify rather than complicate the solution to the policy assignment problem.

On the other hand the analysis also demonstrates the severe constraint that a pegged exchange rate system imposes on the conduct of monetary policy. This constraint is illustrated further under Aspects of the Monetary Approach to the Balance of Payments. That framework also serves to illustrate the more fundamental restrictions on the conduct of fiscal and monetary policy - restrictions that stem from the interdependence among the various policy instruments.

The research reported here is part of the National Bureau of Economic Research's program in International Studies and Economic Fluctuations. Any opinions expressed are those of the author and not necessarily those of the National Bureau of Economic Research. 
The analysis is extended in the subsequent section in order to examine the implications of capital mobility and portfolio balance. The purpose of that analysis is twofold. First, it illustrates the channels through which monetary and fiscal policies operate, as well as the constraints that the international mobility of capital impose on the effectiveness of monetary and fiscal policies. Second, it provides for a useful framework for the comparison between the mechanisms and the speed of adjustment of the economic system under fixed and flexible exchange rate regimes. The section concludes with a more general discussion of the interaction between exchange rate regimes and the constraints on the conduct and effectiveness of macroeconomic policies.

The topic of exchange market intervention is discussed in the next section, where it is argued that the evidence on the relative ineffectiveness of sterilized intervention implies that the open economy constraints on the conduct of monetary policy are unlikely to be alleviated through sterilization policies. The chapter concludes with a discussion of some policy implications.

At the outset it is relevant to note that recent developments in the theory of macroeconomic policy have established conditions for the effectiveness of policies in influencing output and employment which emphasize the distinction between anticipated and unanticipated policy actions, the importance of incomplete information, and the consequences of contracts that fix nominal wages and prices over finite intervals. This chapter, which focuses on the international constraints on macroeconomic policies, does not analyze how these conditions are modified in an open economy. Rather, since the main concern of this chapter is with macroeconomic policy, a principal objective of which is to influence output and employment, it will be assumed that requisite conditions for such influence are satisfied.

\section{The Constraints on Macroeconomic Policies: The Assignment Problem}

The basic theory of macroeconomic policy for the open economy has been advanced by the contributions of James E. Meade and Robert A. Mundell. The key characteristic of these contributions is the perception that considerations concerning the openness of the economy and the implications of the openness to the conduct of policies are fundamental and belong to the center stage of the analysis. This notion is in sharp contrast with the conventional view (which was particularly popular in the United States) that the foreign trade sector is an appendix to the economy which could otherwise be analyzed as if it were closed. More recent developments associated with the implications of the monetary approach to the balance of payments-and more generally with the role played by "rational expectations," which tend 
to nullify the intended effects of policies - have led to doubts about the efficacy (and wisdom) of stabilization policies and have resulted in "policy pessimism."

This section surveys some of the elementary issues relevant for the analysis of policies. Special emphasis is given to the nature of the constraints that the openness of the economy imposes on policymaking. A convenient starting point is Mundell's analysis of the proper assignment of fiscal and monetary policies to the attainment of internal and external balance.

\section{The Assignment Problem: Mundell's Solution (1962)}

Mundell's analysis of the assignment problem serves as a convenient starting point since it was developed against a similar background of policy pessimism. The relevant question at the time was: How can a small open economy that gives up the use of its exchange rate as a policy instrument (by deciding to peg the rate) and that gives up the use of tariffs, quota, and other measures of commercial policy (by abiding by the rules of GAAT), attain simultaneously internal balance and external balance with the use of fiscal and monetary policy? In providing the answer to this question Mundell first recognized that an application of Jan Tinbergen's (1952) policy principle, which states that to attain two independent targets there must be at least two policy instruments, implies that with the aid of two policy instruments (fiscal and monetary policies) there is a way to attain simultaneously internal and external balance. He then extended Tinbergen's principle by developing the effective market classification principle which guides the policymaker (according to the stability criterion) in pairing the two instruments with the objectives on which they have the most influence. To illustrate Mundell's framework, consider the following fully employed small open economy.

Let government spending be $G$ and let private aggregate demand be $E(y, r)$ where $y$ denotes income and $r$ denotes the rate of interest. Assume that aggregate demand depends negatively on the rate of interest. Both the private sector and the government divide their spending between imported goods and domestically produced goods. For simplicity of exposition suppose that both the private sector and the government spend a fraction $m$ on imports and $(1-m)$ on domestically produced goods. Internal balance is attained when aggregate demand for domestic goods equals aggregate supply as in equation 5.1:

$$
(1-m)[E(\bar{y}, r)+G]+\bar{x}=\bar{y}
$$

where $\bar{y}$ denotes full employment income and where $\bar{x}$ denotes the (exogenously given) level of exports representing foreign demand for domestic output. 
External balance is specified as balance of payments equilibrium in which the sum of the surpluses in the current account and the capital account is zero so that there is no need for international reserve flow. Thus, external balance is attained when

$$
\bar{x}-I M+z(r)=0
$$

where $I M$ denotes imports and where $z(r)$ denotes the surplus in the capital account which is assumed to depend positively on the rate of interest. Recalling that imports are a fraction $m$ of the sum of private and government spending, one can write the condition for external balance as

$$
\bar{x}-m[E(\bar{y}, r)+G]+z(r)=0
$$

If monetary policy is defined in terms of changes in the rate of interest and fiscal policy in terms of the rate of government spending, it is clear that in general equations 5.1 and 5.3 can be solved with the appropriate choice of the policy instruments $r$ and $G$. This is the implication of Tinbergen's principle.

The effective market classification principle can be demonstrated using Mundell's diagram. In figure 5-1 the locus $X X$ describes combinations of monetary and fiscal policy which maintain internal balance. Using equation 5.1 the slope of that locus is:

$$
\left.\frac{d r}{d G}\right|_{X X}=\frac{1}{-E_{r}}>0
$$

where $E_{r}$ denotes the partial derivative of private aggregate demand with respect to the rate of interest. In the same figure, the locus $F F$ describes combinations of monetary and fiscal policies that ensure external balance. Using equation 5.3 , the slope of that locus is:

$$
\left.\frac{d r}{d G}\right|_{F F}=\frac{1}{-E_{r}+z_{r} / m}>0
$$

A comparison of the slopes of the $X X$ and $F F$ schedules indicates that as long as $z_{r}>0$ (that is, as long as there is some degree of international capital mobility), the $X X$ schedule is steeper than the $F F$ schedule. The explanation is obvious. A rise in government spending creates an excess demand in the market for goods and induces a deterioration in the balance of trade. The rise in aggregate demand and the deterioration in the balance of trade can be offset by a rise in the rate of interest. The latter, however, also induces an improvement in the capital account of the balance of payments. The relative 
International Interdependence $\cdot 175$
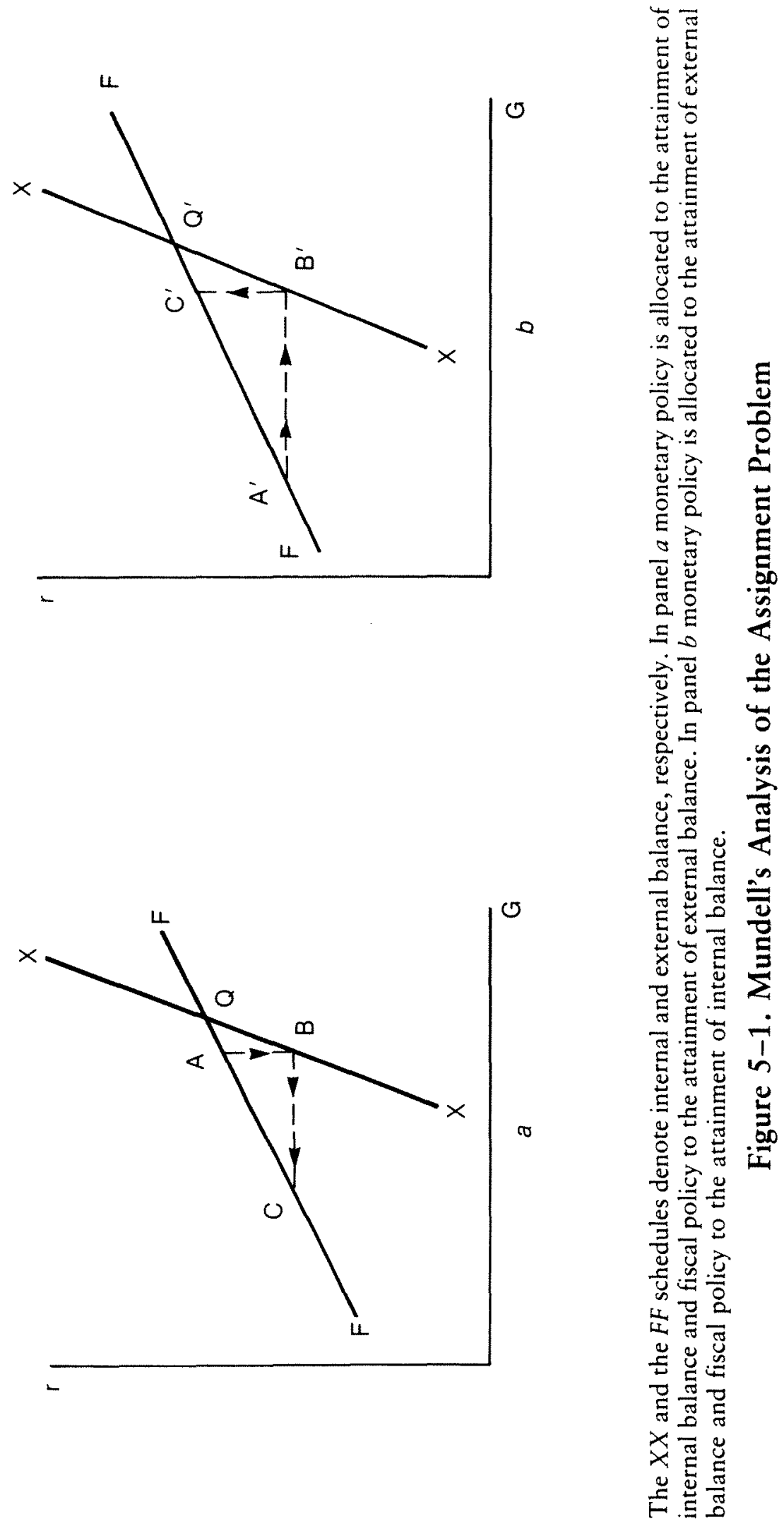
slopes of the two schedules reflect the fact that changes in the rate of interest have a relatively stronger effect on the external balance than on the internal balance. This differential effect arises because the rate of interest affects the capital account in addition to its effect on the balance of trade through the induced changes in aggregate demand.

The differential impact of the two instruments on the two targets has important implications for the proper allocation of responsibilities between the monetary and the fiscal authorities. Consider for example points $A$ and $A^{\prime}$ in panels $a$ and $b$ in figure $5-1$. These points correspond to a position of external balance that is combined with an excess supply of domestic output. Internal balance could be restored by an expansionary monetary policy which lowers $r$ as in panel $a$, or alternatively by an expansionary fiscal policy which raises $G$ as in panel $b$. These policies yield equilibrium at points $B$ and $B^{\prime}$ respectively, which correspond to a position of internal balance combined with a deficit in the balance of payments. The deficit can be eliminated by a fiscal contraction which lowers $G$ as in panel $a$ or by a monetary contraction which raises $r$ as in panel $b$. The external balance is restored at points $C$ and $C^{\prime}$. As is evident, the path that is followed in panel $a$ leads away from the global equilibrium at point $Q$ while the path that is followed in panel $b$ leads progressively toward the global equilibrium, $Q^{\prime}$. The key difference between the two panels is in the allocation of instruments to targets. In panel $a$ the responsibility for external balance was given to the fiscal authority while the responsibility for internal balance was given to the monetary authority. In contrast, panel $b$ corresponds to the opposite allocation where fiscal policy deals with internal balance while monetary policy with external balance. The allocation of instruments according to the effective market classification principle ensures that path $b$ will be followed and yields Mundell's famous propositions that monetary policy ought to be aimed at external balance and fiscal policy at internal balance. This principle imposes a severe constraint on the conduct of policy. A failure to follow this prescription may yield a progressively worsening situation.

Further Developments of the Assignment Problem:

The Role of Capital Mobility

The analysis in the preceding section introduced both the concept of the assignment problem and the notion of Tinbergen's principle about the relationship between the number of targets and the number of independent policy instruments. It also introduced Mundell's principle of the effective market classification. The specific model, however, is subject to a major limitation in that it defines monetary policy in terms of the changes in the rate of interest rather than in terms of open market operations. The difference between the two definitions of monetary policy is fundamental since when capital is 
highly mobile, the monetary authorities may not be able to alter the rate of interest or even to alter the supply of money. In this section I modify the analysis of the assignment problem. ${ }^{2}$ The modification defines monetary policy in terms of open market operations which alter the domestic source component of the monetary base. The analytical framework is that of the standard pegged exchange rates variable output open economy version of the IS-LM model as developed by Mundell $(1961,1963)$ and Fleming (1962), extended by McKinnon and Oates (1966), elaborated further by Swoboda (1972), and surveyed by Mussa (1979).

Equilibrium in the market for domestic output is described by equation 5.6 , where $G$ denotes government spending on domestic goods and where, for simplicity, imports depend only on income.

$$
E(y, r)+\bar{x}-I M(y)+G=y .
$$

Money market equilibrium is described by equation 5.7 where $L(y, r)$ denotes the demand for money and $D+R$ the supply of money; $D$ denotes the domestic source component of the monetary base and $R$ denotes international reserves. The exchange rate is normalized to be unity and the money multiplier is assumed to be unity.

$$
L(y, r)-(D+R)=0
$$

Finally, external balance is attained when the balance of payments is balanced as in equation 5.8:

$$
\bar{x}-I M(y)+z(r)=0
$$

From equations 5.6 and 5.7 the impact effects of fiscal and monetary policies on income and the rate of interest can be expressed as

$$
\begin{gathered}
d y=-\frac{L_{r}}{\Delta} d G-\frac{E_{r}}{\Delta} d D \\
d r=\frac{L_{y}}{\Delta} d G-\frac{s+m}{\Delta} d D
\end{gathered}
$$

where $\Delta=-(s+m) L_{r}-E_{r} L_{y}>0, s$ and $m$ denote the marginal propensities to save and import respectively, $L_{r}$ denotes the negative effect of a change in the rate of interest on the demand for money, and $L_{y}$ denotes the inverse of the velocity of circulation.

In general these changes in income and the rate of interest will not persist for the long run since as long as the balance of payments is imbalanced, the money supply is being changed, and, as a result, income and the rate of 
interest are altered. From equation 5.8, the change in reserves (the balance of payments) can be expressed as

$$
\frac{d R}{d t}=-m d y+z_{r} d r
$$

where $d R / d t$ denotes the change in reserves per unit of time. Using equations 5.9 and 5.10 in 5.11 , the equilibrium change in reserves can be written as

$$
\frac{d R}{d t}=\frac{m L_{r}+z_{r} L_{y}}{\Delta} d G+\frac{m E_{r}-z_{r}(s+m)}{\Delta} d D .
$$

Equation 5.12 with $(d R / d t)=0$, expresses the combinations of fiscal and monetary changes that are necessary for the maintenance of external balance.

The internal balance condition is defined in terms of the attainment of a given level of income so that $d y=0$. From equation 5.9, the slope of the internal balance schedule $X X$ in figure $5-2$ is

$$
\left.\frac{d D}{d G}\right|_{X X}=\frac{-L_{r}}{E_{r}}<0 .
$$

This slope indicates that in order to maintain a given level of income, an expansionary monetary policy must be accompanied by a contractionary fiscal policy. All points to the right of the $X X$ schedule correspond to an excess demand for output while points to the left correspond to excess supply.

From equation 5.12 (with $d R / d t=0$ ) the slope of the external balance schedule $F F$ is

$$
\left.\frac{d D}{d G}\right|_{F F}=\frac{m L_{r}+z_{r} L_{y}}{(s+m) z_{r}-m E_{r}} \gtreqless 0 .
$$

All points above the $F F$ schedule correspond to a deficit in the balance of payments and all points below the schedule correspond to a surplus. As may be seen, the slope of the external balance schedule depends on the degree of capital mobility. If the degree of capital mobility is relatively low, $m L_{r}+$ $z_{r} L_{y}<0$ and the schedule is negatively sloped. Conversely, when the degree of capital mobility is relatively high, $m L_{r}+z_{r} L_{y}>0$ and the schedule is positively sloped. The economic interpretation is straightforward. A rise in government spending raises income and the rate of interest. The rise in income induces a deterioration in the balance of trade while the rise in the rate 
International Interdependence 179

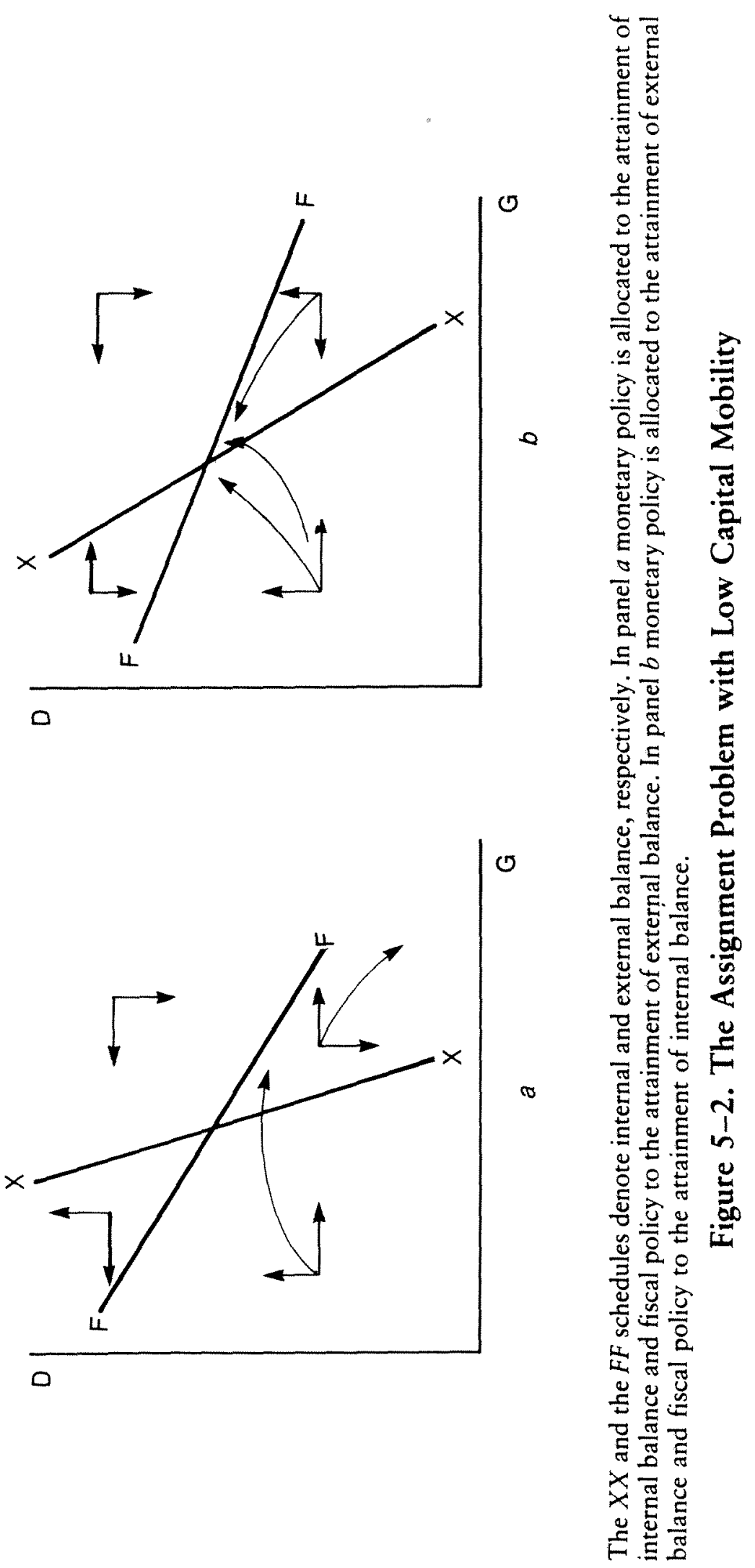


of interest induces an improvement in the capital account. If capital is highly mobile, the improvement in the capital account will exceed the deterioration in the balance of trade; the balance of payments will be in surplus which could be corrected by an expansionary credit policy. In contrast, if the degree of capital mobility is relatively low, the deficit in the balance of trade will exceed the surplus in the capital account, and the overall balance of payments will be in deficit which could be corrected by a contractionary credit policy.

The following analysis shows that the solution to the assignment problem depends in a fundamental way on the degree of capital mobility. Consider first the case where capital is relatively immobile. In that case the external balance schedule is negatively sloped and, as can be seen by a comparison of equations, 5.13 and 5.14, the external balance schedule is flatter than the internal balance schedule. Figure 5-2 describes the implications of two alternative assignments of fiscal and monetary policies. As may be seen, the implications of Mundell's analysis remain intact. When fiscal policy is assigned to attaining external balance and monetary policy is assigned to attaining internal balance as in panel $a$, the system becomes unstable as the situation gets progressively worse. In contrast, under the opposite assignment, as in panel $b$, the system is stable and the point of global equilibrium is reached.

Consider next the case in which capital is highly mobile. In that case the $F F$ schedule is positively sloped and the implications of the two alternative assignments of fiscal and monetary policies are described in figure 5-3. A comparison of panels $a$ and $b$ of figure 5-3 shows that in contrast with the previous analysis, both solutions to the assignment problem lead to a stable system. It is in this context that one may argue that a liberalization of capital flows and a removal of controls may contribute to greater flexibility in the use of fiscal and monetary policies for the small open economy. The reason is that when capital is highly mobile, these policies do not need to be rigidly tight for the attainment of specific targets, as in the case in which the degree of capital mobility is not too high.

The key difference between the two solutions lies in the dynamics. As is seen, in panel $a$ of figure 5-3, the direction of the path to global equilibrium is clockwise while the direction of the path in panel $b$ is counterclockwise. The difference between the two paths may be significant once one considers the delays and the costs that are associated with changes in the course of macroeconomic policies. For example, it is reasonable to assume that it is relatively easy to agree on the proper policies when the attainment of both targets require expansionary or contractionary actions. The problem arises in the case of a conflict. When the attainment of one target calls for an expansionary policy while the attainment of another target calls for a contractionary policy, the choice between panels $a$ and $b$ may be significant. As is evident from panel $a$ following the phase during which fiscal and monetary policies move in the same direction (an expansion or a contraction), there is 

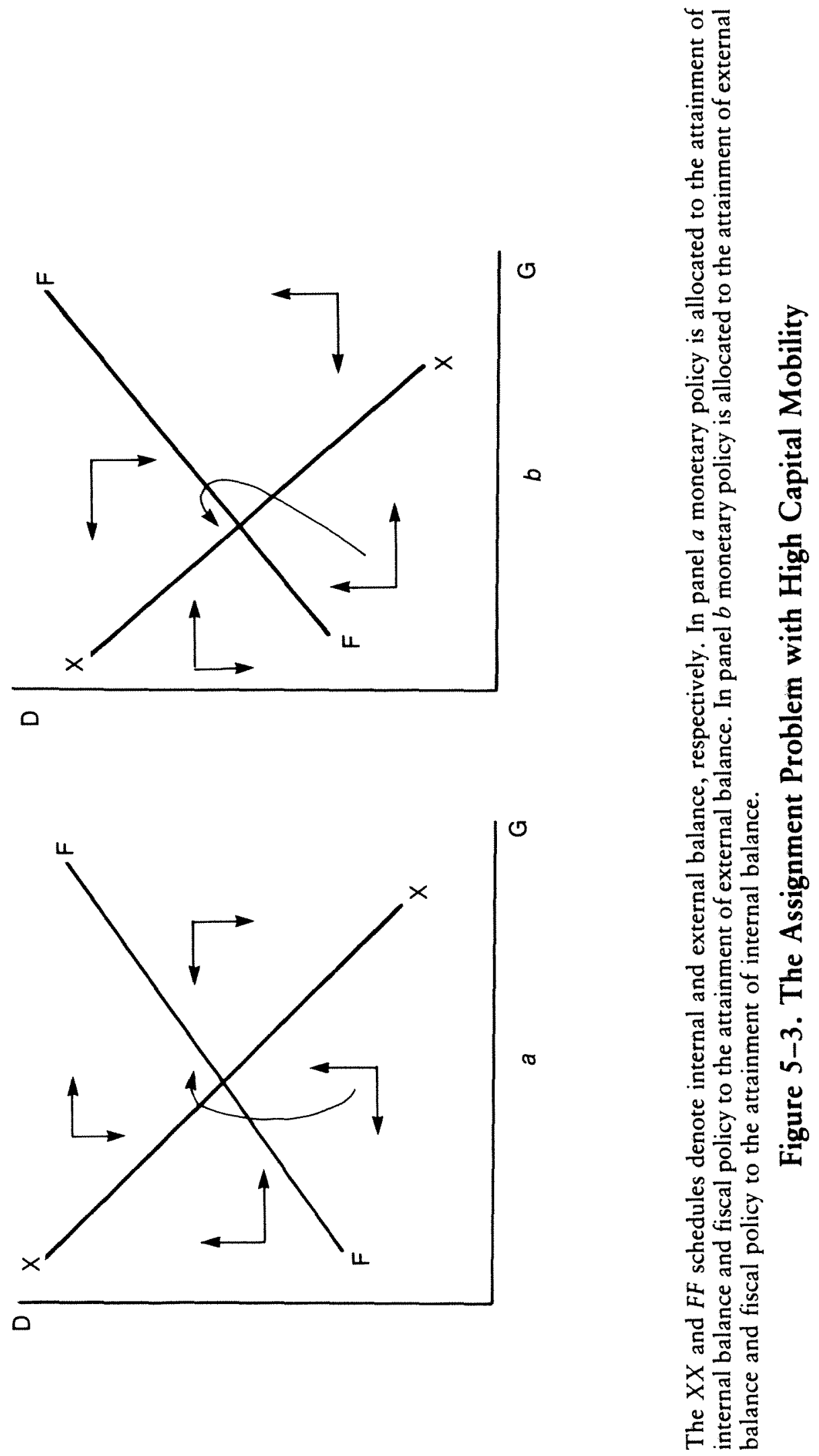
always a phase during which fiscal policy continues in its course while monetary policy changes direction. In contrast in panel $b$ fiscal policy is always the instrument which changes direction following the phase in which both instruments operated in the same (expansionary or contractionary) direction. To the extent that in circumstances of conflict between policies, it is easier to alter the monetary instrument than it is to alter the fiscal instrument (which might require legislation), the path in panel $a$ might be superior to the path in panel $b$, and the proper allocation of instruments to targets would not be the conventional one. In that case fiscal policy would be assigned to the external target while monetary policy would be assigned to the internal target. Nevertheless, and in contrast with the standard analysis, if capital is highly mobile this alternative assignment would still yield a stable path. Hence, under such circumstances the open economy constraint on the policy mix may not be as severe.

The analysis in this section examined the implications of the open economy IS-LM model for the solution to the assignment problem. Before leaving this model it is worth pointing out some of its key features. First, and most important, the specification of the model recognizes that under a pegged exchange rate system the money supply is endogenous. This simple proposition follows from Tinbergen's principle concerning the necessary relationship between the number of instruments and targets. Once the monetary authority commits the money supply process to the maintenance of a specific target exchange rate, it cannot use this instrument to achieve other targets. Under these circumstances the money. supply instrument has to be set at that level which is consistent with the maintenance of the given exchange rate. Further, the model incorporates explicitly considerations of money market equilibrium. This brings to the forefront the notion that under a pegged exchange rate system, the nominal quantity of money is determined by the private sector's demand and, therefore, open market operations may not succeed in altering the nominal quantity of money. The effects of such policies may only be reflected in changes in the asset composition of the central bank. For example, an open market purchase which raises $D$ (the domestic source component of the monetary base) results in a reduction in $R$ (international reserves) without inducing a change in the money supply. This dependence of the balance of payments (the change in international reserves) on the relationship between the demand for money and the rate of credit expansion is one of the major constraints that a pegged exchange rate system imposes on the conduct of macroeconomic policy. This constraint is among the key characteristics of the monetary approach to the balance of payments. The next section uses some elements in order to illustrate additional constraints on the conduct of macroeconomic policies in the open economy. 


\section{Aspects of the Monetary Approach to the Balance of Payments: The Constraints and Interdependencies of Policies}

The monetary approach to the balance of payments states that the balance of payments is essentially (though not exclusively) a monetary phenomenon. Since in recent years there have been numerous expositions of the monetary approach (see for example the expositions in Johnson, 1958, Dornbusch, 1980, and Frenkel and Mussa, 1985), I will only sketch here some of its policy implications.

Consider the following simple monetary model. Let the demand for money $L$ be proportional to income as in equation 5.15:

$$
L=k Y
$$

and, as before, let the supply of money $M$ be

$$
M=R+D
$$

Money market equilibrium requires equality between the demand the supply of money as in eqaution 5.17:

$$
k Y=R+D
$$

By differentiating equation 5.17 with respect to time, one can express the rate of change of international reserves (the balance of payments) as

$$
\frac{d R}{d t}=k \lambda Y-\frac{d D}{d t}
$$

where $\lambda$ denotes the percent rate of growth of income, $k \lambda y$ denotes the flow demand for money, and $d D / d t$ denotes the rate of credit expansion. Equation 5.18 states that in the absence of credit expansion, the flow demand for money is satisfied by an equal accumulation of international reserves which is brought about through a surplus in the balance of payments. Furthermore, for a given flow demand for money, any attempt to increase the supply by credit expansion will be offset by a corresponding decline in international reserves. This reiterates the fundamental fact that the necessary consequence of pegging the exchange rate is a loss of control over the supply of money.

This analysis has emphasized the intimate relationship between the demand for money, monetary policy, and the balance of payments. What are the effects of other macroeconomic policies? In order to examine these issues, 
one extends the analytical framework so as to incorporate government spending, taxes, and the budget. Assume that government spending $G$ is a constant fraction $g$ of national income

$$
G=g y
$$

and assume that the proportional income tax rate is $\tau$. Assume further that international reserves are held in interest earning assets which yield a rate of return of $r$ percent per unit of time. It follows that the government budget constraint is

$$
G=\tau Y+r R+d D / d t
$$

which states that government spending, $G$, can be financed by taxes, $\tau y$, by the return on reserve holdings, $r R$, and by credit expansion, $d D / d t$. Substituting equation 5.19 and 5.20 into 5.18 yields

$$
\frac{d R}{d t}=[k \lambda-(g-\tau)] Y+r R
$$

Equation 5.21 indicates that a rise in government spending worsens the balance of payments while a rise in the growth of income, in the tax rate, and in the return on reserve holdings improves the balance of payments. Further, ceteris paribus a balanced-budget rise in government spending (so that $d g=$ $d \tau$ ) will not affect the balance of payments. This analysis demonstrates the intimate relationship between the budget deficit, the rate of credit expansion, and the balance of payments, which are interconnected by the budget constraints of the government and of the private sector. These constraints imply that in a fundamental sense not all policy instruments are independent and, therefore, it may not always be appropriate to treat monetary and fiscal policies as two independent instruments of policy.

It should be emphasized that these interrelationships are not specific to the monetary approach to the balance of payments. Rather, they are a reflection of the fundamental identities of national income accounting according to which national product must equal the sum of private aggregate demand $E$ (absorption), government spending $G$, and net foreign demand-the surplus in the balance of trade $(X-I M)$.

$$
y=E+G+(X-I M) .
$$

By subtracting total taxes (denoted by $T$ ) from both sides of 5.22 and rearranging, we obtain 


$$
(X-I M)=[(y-T)-E]+(T-G)
$$

which expresses the surplus in the current account (which equals the balance of payments in the absence of capital movements) as the sum of private savings (the excess of disposable income over spending) and public savings (the budget surplus). The same idea is expressed in equation 5.21 , in which private savings is the flow demand for money $k \lambda Y$, while the budget surplus is $r R+(\tau-g) Y$.

From the policy perspective, equation 5.23 emphasizes that what matters for determining the current account of the balance of payments is the total level spending rather than the composition of spending between domestic and foreign goods. It follows that for a given level of income, the only effective balance of payments policies are those which are either expenditure-reducing or expenditure-increasing policies. Under these circumstances expenditureswitching policies which alter the composition of spending between imports and domestically produced goods will not be effective. Since this policy implication is derived directly from the identities of national income accounting, they are not specific to the monetary approach and should characterize any model with similar features.

The emphasis on the relationship between total income and total expenditures is the key insight of Alexander's (1952) absorption approach to the balance of payments. As a policy matter, however, there may be room for expenditure switching policies once the existing structure of relative prices in the economy does not correspond to the equilibrium price structure. To illustrate the point and to introduce the notion of relative prices, it is necessary to disaggregate total output as in Dornbusch (1974). Consider an economy that produces traded and nontraded goods, and denote the relative price of nontraded goods by $p_{N}$. The value of output (using traded goods as a numeraire) is

$$
y=y_{T}+p_{N} y_{N}
$$

where $y_{T}$ and $y_{N}$ denote the rates of production of traded and nontraded goods respectively. The value of private spending is

$$
E=E_{T}+p_{N} E_{N}
$$

where $E_{T}$ and $E_{N}$ denote private spending on traded and nontraded goods, respectively. Government spending $G$ is also allocated between the two goods so that

$$
G=G_{T}+p_{N} G_{N}
$$


where $G_{T}$ and $G_{N}$ denote government spending on traded and nontraded goods, respectively. Subtracting equation 5.25 from 5.24 yields

$$
y-E=\left(y_{T}-E_{T}\right)+p_{N}\left(y_{N}-E_{N}\right)
$$

To introduce the effects of government spending, subtract total taxes $T$ from both sides of 5.27 and add and subtract government spending to the righthand side using equation 5.26. After rearranging this yields

$$
(X-I M)=[(y-T)-E]+(T-G)+p_{N}\left[\left(E_{N}+G_{N}\right)-y_{N}\right]
$$

where the balance of trade $(X-I M)$ was substituted for the excess supply of traded goods $y_{T}-\left(E_{T}+G_{T}\right)$.

It is clear from equation 5.28 that the balance of trade (or the balance of payments in the absence of capital movements) can be described and analyzed in terms of three basic magnitudes: (1) the excess of private disposable income over expenditures, (2) the excess of public income over expenditures (the budget surplus), and (3) the excess demand for nontraded goods. The first two components have been discussed and introduced in equation 5.23. The third component reflects a "disequilibrium" relative price structure that prevents market clearing for nontraded goods. The first two components reflect the traditonal factors emphasized by the absorption approach. They relate to aggregate private and government spending which could only be influenced by expenditure-increasing or by expenditure-reducing policies. On the other hand the third component could be influenced by expenditureswitching policies that alter the relative price structure. This formulation highlights the fundamental constraint on open economy macroeconomic policy. These constraints are "model free." They stem from the fundamental identities of national income accounting that link the trade balance to the government budget, to the discrepancies between aggregate spending and disposable income and between demand and supply of home goods.

The foregoing analysis of the constraints on the conduct of macroeconomic policy in the open economy focused on the general implications of the "assignment problem" and of the national income accounting identities as reflected by the propositions of the "absorption" and "monetary" approaches to the balance of payments. The next section examines in greater detail some of the constraints that are imposed by the integration of international capital markets.

\section{Capital Mobility and the Constraints on Macroeconomic Policies under Fixed Exchange Rate Regimes}

As indicated in my opening paragraphs, one of the central linkages between national economies operates through the international mobility of capital 
which links interest rates on financial assets. In addition, by permitting countries to finance current account imbalances, this mobility provides for a channel through which macroeconomic disturbances are transmitted internationally. What are the constraints that such mobility of capital imposes on the conduct of policy?

\section{International Capital Mobility and Domestic Stabilization}

International capital mobility imposes a severe constraint on the use of monetary policy for domestic stabilization purposes. Under a fixed exchange rate, an increase in the domestic credit component of the money supply in a small open economy may temporarily reduce interest rates on domestic securities, but it will induce a capital outflow and a corresponding loss of foreign exchange reserves that will rapidly reduce the money supply back to its previous equilibrium level. Monetary expansion by a large country, which affects conditions in world financial markets, can be somewhat more effective in influencing domestic prices, output, and employment. However, even a large country will suffer a loss of foreign exchange reserves that is inversely related to its size in the world economy. Sterilization operations of a central bank may temporarily insulate the domestic money supply from changes in foreign exchange reserves, but, in the long run, sterilization cannot sustain a money supply that differs from the equilibrium level of money demand. Under a flexible exchange rate, a government regains long-run control over the nominal money supply. However, international capital mobility still limits the effectiveness of monetary policy. Any increase in aggregate demand induced by lower domestic interest rates is partially dissipated in increased expenditures on imported goods, financed by international capital flows. Moreover, exchange rate adjustments that occur rapidly in response to perceived changes in monetary policy are likely to lead to rapid adjustments of domestic prices and wage rates, thereby limiting the effect of monetary policy on output and employment. ${ }^{3}$

The implication of capital mobility on the efficiency of policies is illustrated in figure 5-4, which highlights the role of portfolio balance and describes the effects of open market operations under alternative exchange rate regimes. ${ }^{4}$ Consider a portfolio composed of real cash balances $M / P$ (where $P$ denotes the price level) and common stocks $K$. Let the price of a security in terms of goods be $p_{k}$. It is assumed that the economy is small and fully integrated in world capital markets. As a result, since the foreign rate of interest is assumed to be given, the relative price of securities in terms of goods, $p_{k}$, is also assumed to be fixed for the small open economy. The price level $P$ for the small open economy is assumed to equal $S P^{*}$ where $S$ denotes the exchange rate and $P^{*}$ denotes the given foreign price. Thus, under fixed exchange rates the price level is given. The value of wealth $W$ is thus

$$
W=\frac{M}{S P^{*}}+p_{k} K
$$




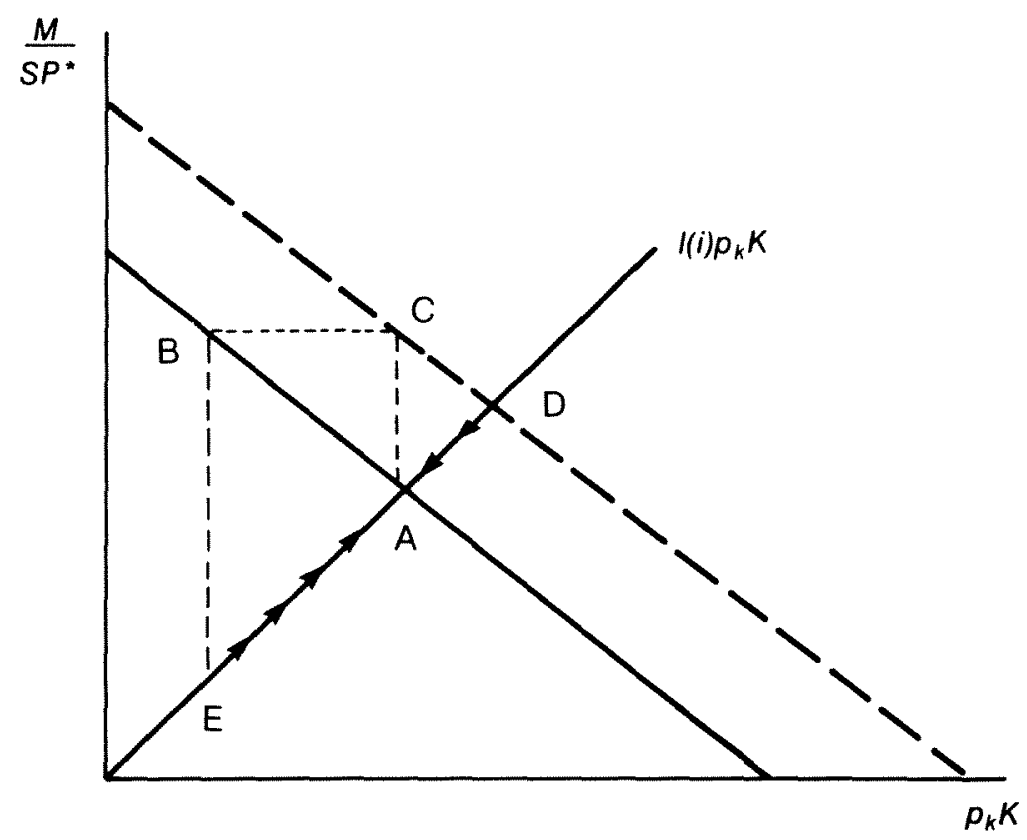

Figure 5-4. Portfolio Equilibrium and the Effects of Monetary Policy under Fixed and Flexible Exchange Rate Regimes

Suppose that the desired ratio of money to securities depends negatively on the rate of interest as in equation 5.30 .

$$
\frac{M}{S P^{*}}=l(i) p_{k} K
$$

Portfolio equilibrium is described by point $A$ in figure 5-4. The negatively sloped schedule describes the wealth constraint and the positively sloped schedule describes the desired composition of assets given the rate of interest. An open market purchase moves the economy from point $A$ to point $B$ at which the money supply has risen and the holdings of securities by the private sector have fallen. Since at point $B$ the composition of the portfolio has been disturbed and since asset holders have access to world asset markets at the given rate of interest, they will restore portfolio equilibrium instantaneously by exchanging the increased stock of cash for foreign securities and thereby returning to point $A$. Thus, the facts that world capital markets are integrated and that open market operations are conducted in assets traded internationally at a given price, enable the private sector to nullify the actions of the monetary authority. In fact, in this case open market operations amount to an exchange of foreign exchange reserves for securities between 
the monetary authorities and foreign asset holders, and the entire process of adjustment is effected through the capital account of the balance of payments. The leverage of monetary policy can be somewhat enhanced if it operates in financial assets that are isolated from world capital markets since, in the short run, the link between the rates of return on such assets and the world rates of interest is not as tight.

The same figure can be used for the analysis of a once-and-for-all rise in the quantity of money that is brought about through an unanticipated transfer of cash balances that moves the economy from point $A$ to point $C$. The impact of this policy is to raise the value of assets and to raise the relative share of money in wealth. Portfolio composition equilibrium is restored by an immediate exchange of part of the increased monetary stock for equities as individuals move to point $D$. This exchange is effected through the capital account of the balance of payments. Since at $D$ the value of assets exceeds the equilibrium value at $A$, individuals will wish to run down their holdings of both equities and real cash balances by increasing expenditures relative to income. This part of the process will be gradual. The transition toward longrun equilibrium follows along the path from $D$ to $A$ and is characterized by a deficit in the current account, a surplus in the capital account, and a deficit in the monetary account of the balance of payments.

Under flexible exchange rates, adjustments of real balances occur through changes in the exchange rate. Using the same diagram the effects of monetary policies are very different. An open market operation bringing the economy from point $A$ to point $B$ in figure 5-4 cannot be nullified through the capital account since under flexible exchange rates money ceases to be an internationally traded commodity. Portfolio equilibrium is restored by an immediate rise in the exchange rate (a depreciation of the currency), which moves individuals from point $B$ to point $E$. As may be seen, the percent rise in the exchange rate exceeds the percent rise in the money stock; this is the overshooting phenomenon. Since at $E$ the value of assets fall short of the long-run equilibrium value, individuals will wish to accumulate both equities and real balances by reducing expenditures relative to income. This part of the process will be gradual, while the transition from $E$ to $A$ is characterized by a surplus in the current account, a deficit in the capital account, and an appreciation of the currency. ${ }^{5}$

In contrast, when the rise in the quantity of money is brought about through a transfer moving the economy from point $A$ to point $C$, the new equilibrium will be restored instantaneously through an equiproportionate depreciation of the currency, which restores equilibrium at $A$.

The previous analysis of open market operations assumed implicitly that the returns on government holdings of securities are rebated to the private sector (in a lump sum fashion) but that the private sector does not capitalize the expected future flow of transfers. As a result the open market operations 
did not change the wealth position of individuals who moved from point $A$ to point $B$ along the given wealth constraint. Under the alternative assumption that asset holders anticipate and capitalize the flow of transfers and treat them as any other marketable asset, they effectively conceive of the equities that are held by the government as their own. In that case the open market purchase only raises the supply of real cash balances and moves the economy from point $A$ to point $C$. The effects of this policy are identical to the effects of the pure monetary expansion that is brought about through the governmental transfer.

The analysis of these two extreme cases implies that when international capital markets are highly integrated, the effectiveness of the constraints on monetary policy under fixed and flexible exchange rate regimes depends on the degree to which the private sector capitalizes future streams of taxes and transfers as well as on the marketability of claims to such streams. ${ }^{6}$ When such claims are not fully perceived by individuals or by the capital market, the effects of open market operations are nullified rapidly under fixed exchange rates while the adjustment is gradual under flexible exchange rates. In contrast, when individuals and capital markets do fully perceive these claims, the adjustment to open market operations is only gradual when the exchange rate is fixed, while it is rapid when the exchange rate is flexible. These cases illustrate that the ranking of alternative exchange rate regimes according to the speed of adjustments to monetary policies and the division of the adjustment process between the current and capital accounts, are not unambiguous since they depend on the mechanism of monetary policy and on the public's perception of such policies.

\section{Domestic Capital Mobility}

A high degree of capital mobility also implies a low degree of effectiveness of fiscal policy. Under a flexible exchange rate, a fixed domestic money supply and a domestic interest rate fixed by conditions in world markets (and by exchange rate expectations that affect the forward discount or premium on foreign exchange) impose a strict constraint on the level of domestic income that is consistent with monetary equilibrium. Fiscal policy actions do not affect this constraint (except possibly by altering exchange rate expectations) and, hence, cannot affect the equilibrium level of domestic income. Under a fixed exchange rate, the money supply is not fixed because the capital inflow induced by an expansionary fiscal policy will increase the foreign exchange reserves of the monetary authority. The initial expansionary effect of any fiscal stimulus, however, is limited by the extent to which it falls on domestically produced goods that are not close substitutes for imports; and the subsequent multiplier effects of any fiscal stimulus are limited by the high marginal propensity to spend on internationally traded goods. 
To achieve the maximum effect from fiscal and monetary policy in open economies, it follows that such policies should be directed toward goods and assets that are isolated from world trade, that is, toward goods and assets for which the home country is "large" relative to the size of the market. Changes in government expenditures on nontradable goods are likely to be more effective in influencing domestic output and employment than are changes in government expenditure on internationally traded goods. Similarly, open market operations involving financial assets that are not close substitutes for international financial assets are more likely to influence interest rates and thus other macroeconomic variables. This does not imply, however, that it is desirable to artificially restrict trade and capital movements in order to enhance the effectiveness of macroeconomic policy. Such restrictions have an important cost in terms of reducing the benefits that a country derives from integration of markets. Moreover, substitution possibilities among goods and among financial assets limit the effectiveness of restrictions on trade and capital movements.

\section{International Exchange and Monetary Equilibrium Requirements}

The international exchange of national monies and the requirement of monetary equilibrium also impose a severe limitation on the effectiveness of monetary policy. As stated before, under a fixed exchange rate regime the authorities lose control over the nominal money stock, while under a flexible rate regime the requirements of monetary equilibrium ensures that in the long run, changes in the nominal money stock lead to a proportionate change in all nominal prices and wages. Because of the rapid change in the exchange rate, the constraint on monetary policy that is implied by the homogeneity postulate is likely to be manifested much more promptly in an open economy with flexible exchange rates than in a closed economy.

An additional consideration constraining the conduct of macroeconomic policy follows from the dynamic linkage between current exchange rates and expectations of future exchange rates (see Mussa, 1976, 1984). This dynamic linkage implies that the effect of a given policy on the exchange rate, and thereby on other economic variables, depends on its effect on expectations concerning future policies. These expectations, in turn, are influenced by the past and by the current course of policy, and it is likely that the mere recognition of this dynamic linkage will influence the conduct of policy. Being aware that the effectiveness of any particular policy measure depends on the way by which it influences the public's perception of the implications of the measure for the future conduct of policy may constrain the government in employing its policy instruments. This mechanism, which is likely to be especially operative under a flexible exchange rate regime, imposes an additional constraint on the conduct of macroeconomic policy in the open economy. 
The foregoing discussion focused on the implications of capital market linkages on the conduct of macroeconomic policy in an open economy. An additional linkage operates through international trade in goods and services. Such trade, which links the prices of goods produced and consumed in different national economies, has at least three implications for the conduct of policy. First, according to the principle of purchasing power parity, the price level in one country (in terms of domestic money) should equal the price level in a foreign country (in terms of foreign money) multiplied by the exchange rate between domestic money and foreign money. Because of transport costs, trade barriers, different weighting schemes for price indexes, and changes in relative prices of nontraded goods, this link is not rigid; but the evidence indicates that this principle holds fairly well over long periods (though it has weakened during the 1970s). The key implication of purchasing power parity is that a country cannot chose its long-run inflation rate independently of its long-run monetary policy and the long-run behavior of its exchange rate. A country, particularly a small country, that fixes the exchange rate between its domestic money and the money of some foreign country will experience a domestic inflation rate and a domestic rate of monetary expansion that are strongly influenced by the monetary policy of that foreign country. This is so even if changes in real economic conditions (which are largely independent of domestic monetary policy) induce divergences from strict purchasing power parity.

Second, the world monetary system and the conduct of national monetary policies must allow for changes in equilibrium relationships between national price levels induced by changes in relative prices of internationally traded goods and nontradable goods. To maintain a system of fixed exchange rates, changes in equilibrium relationships among national price levels must be accommodated by differentials among national inflation rates, supported by appropriate national economic policies. Under a system of controlled or managed floating, it is essential that countries either allow their inflation rates or the rates of change of exchange rates to accommodate equilibrium changes in relative national price levels. A rule that rigidly links changes in the exchange rates to changes in domestic and foreign prices, in accord with relative purchasing power parity, is not consistent with this requirement.

Third, macroeconomic policy can do little to offset changes in equilibrium levels of real income resulting from changes in relative prices of internationally traded goods. A case in point is the 1970 s increase in the relative price of oil. Monetary policy can influence the extent to which the change in the relative price of oil affects general price levels and perhaps short-run levels of employment in oil-exporting and oil-importing countries. Tax and expenditure policies can affect the extent to which gains and losses of real income are translated into changes in real expenditure, or are financed by changes in 
foreign lending and borrowing. By influencing the level and distribution of real expenditure, fiscal policy can also affect the relative prices of nontradable commodities and the distribution of the change in real national income among individuals within the economy. However, neither monetary nor fiscal policy can alter to any appreciable extent the average change in the long-run level of real expenditure resulting from a change in the relative prices of internationally traded commodities that are beyond the control of national economic policies.

In summary, the openness of the economy imposes constraints on the conduct of macroeconomic policy. These constraints may be reflected either in a reduced ability to influence the instruments of monetary policy (such as the nominal money supply under fixed exchange rates), in a reduced ability to influence the targets of monetary and fiscal policy (such as the levels of output and employment), or in an increased prudence in the use of policy because of the potentially undesirable effects on expectations. Similar considerations apply to both fiscal and monetary policies under fixed as well as flexible exchange rate regimes. In fact, the overall government budget constraint provides the link among monetary policy, budgetary policy, and other manifestations of macro policies; this interdependence makes the distinction among the various policy instruments less sharp.

This discussion suggests that while the exchange rate regime affects the nature of the constraints on policy, the constraints themselves stem from the openness of the economy. Furthermore, the choice of the exchange rate regime does not alleviate the fundamental constraints even though it influences the manifestation of these constraints. With this perspective one may rationalize the empirical findings that countries' behavior with respect to international reserve holdings has been more stable than what would have been predicted on the basis of the large changes in the legal arrangement.

Policymakers seem to have recognized that a move to a regime of clean float, which could have reduced the need for reserves, would have imposed significant costs associated with prompt translation of monetary changes into exchange rate changes as well as with large changes in real exchange rates. In view of these costs, policymakers have chosen to enjoy fully the "degree of freedom" that would have been granted to them by a move to clean float. Rather, the key finding reported in Frenkel (1983b) is that in spite of the large change in the legal framework associated with the breakdown of the Bretton Woods agreement and formalized by the various amendments to the Articles of Agreements of the International Monetary Fund, countries have continued to use international reserves and have continued to intervene in the markets for foreign exchange. As a matter of fact, an observer of the patterns of countries' holdings and usages of international reserves would be hard pressed to detect a drastic change in the patterns of holdings of international reserves corresponding to the drastic changes in the legal commitment concerning 
exhange market intervention. The change in economic behavior has been much less pronounced than expected on the basis of the theory concerning the benefits from the additional degree of freedom granted by the flexible exchange rate regime.

The constraints on the conduct of economic policy depend on the exchange rate regime. Therefore, the question of the country's choice of the optimal set of constraints on its policy instruments can be answered in terms of the analysis of the choice of the optimal exchange rate regime. Such analysis reveals that in analogy with Poole's (1970) analysis for the closed economy, the optimal exchange rate regime depends on the nature and the origin of the stochastic shocks that affect the economy as well as on the indexation rules that govern labor markets. (For details see Frenkel and Aizenman, 1982, and Aizenman and Frenkel 1985).

Finally, in concluding the discussion of the interactions between macroeconomic policies and the choice of optimal exchange rate regime as well as interactions between the exchange rate regime and the choice of optimal macroeconomic policies, it is relevant to recall one of the popular arguments put forward in favor of a pegged exchange rate. The argument is based on the "discipline of the exchange." Accordingly, it is argued that the obligation to peg the rate or to follow a predetermined intervention rule would alter fundamentally the conduct of policy by introducing discipline.

In evaluating this argument two points are noteworthy. First, it is not obvious at all that a flexible exchange rate regime exerts less discipline than a fixed rate regime. In fact, since changes in exchange rates are highly visible and are transmitted promptly into domestic prices, the consequences of undisciplined policies are readily apparent. In contrast, undisciplined policies under fixed exchange rates show up only in reserve changes, and then only after a significant delay. It stands to reason, therefore, that in principle a flexible exchange rate regime may also introduce discipline.

The second point is somewhat more general as it sheds doubts on the basic logic underlying the discipline argument. Accordingly, it is argued that national governments are unlikely to adjust the conduct of domestic policies and be disciplined by the exchange rate regime. Rather, it may be more reasonable to assume that the exchange rate regime is more likely to adjust to whatever discipline national governments choose to have. Accordingly, it is not the exchange rate regime that constrains economic policy, but rather the prevailing policy that constrains the choice of the exchange rate regime. It may be noted in passing that this is indeed one of the more potent arguments against the restoration of the gold standard. If governments were willing to follow policies consistent with the maintenance of a gold standard, then the standard itself would not be necessary; if however, governments are not willing to follow such policies, then the introduction of the gold standard per se will not restore stability since, before long, the standard will have to be aban- 
doned. In short, no exchange rate system can protect us from bad policies.

\section{Can Exchange Market Intervention Alleviate the Constraints on Monetary Policy?}

The analysis of the international constraints on monetary policy is closely related to the analysis of the questions of whether the authorities can sterilize the monetary implications of the balance of payments and the monetary implications of interventions in the market for foreign exchange. It is the need for occasional interventions in the market for foreign exchange that provides some of the rationale for the continued stable holdings of international reserves documented in Frenkel (1983b). In this context, however, the difficulties in analyzing that question start with definitions since exchange market intervention means different things to different people (see Wallich, 1982). Some, especially in the United States, interpret foreign exchange intervention to mean sterilized intervention, that is, intervention that is not allowed to affect the monetary base and thus amounts to an exchange of domestic bonds for foreign bonds. Others, especially in Europe, interpret foreign intervention to mean nonsterilized intervention. Thus, for the Europeans an intervention alters the course of monetary policy, while for the Americans it does not.

The distinction between the two concepts of intervention is fundamental, and the exchange rate effects of the two forms of intervention may be very different depending on the relative degree of substitution among assets. In principle, sterilized intervention may affect the exchange rate by portfoliobalance effects (see Allen and Kenen, 1980, Branson 1979, and Henderson, 1977), and by signaling to the public the government's intentions concerning future policies, thereby changing expectations (see Mussa 1981). To the extent that sterilized intervention is effective in managing exchange rates, the constraint on the conduct of monetary policy would not be severe since the undesirable exchange rate effects of monetary policy could be offset by policies that alter appropriately the composition of assets.

In practice, however, the evidence suggests that nonsterilized intervention which alters the monetary base has a strong effect on the exchange rate while an equivalent sterilized intervention has very little effect (see Obstfeld, 1983), as well as the various intervention studies conducted by the board of governors of the U.S. Federal Reserve System and other central banks). These findings are relevant for both the theory of exchange rate determination and the practice of exchange rate and monetary policies. As to the theory, they shed doubts on the usefulness of the portfolio-balance model. As to the practice, they demonstrate that the distinction between the two forms of inter- 
vention is critical if the authorities mean to intervene effectively, and that it is inappropriate to assume that the open economy constraints on monetary policy can be easily overcome by sterilization policies. A more reasonable inference is that it is very difficult to conduct effectively independent monetary and exchange rate policies.

The preceding discussion defined interventions in terms of transactions involving specific pairs of assets. In evaluating these transactions it might be useful to explore the broader spectrum of possible policies. Figure 5-5 summarizes the various patterns of domestic and foreign monetary policies and foreign exchange interventions. These policies are divided into three groups as follows:

I : domestic nonsterilized foreign exchange intervention

$I^{*}$ : foreign nonsterilized foreign exchange intervention

II : domestic monetary policy

$\mathrm{II}^{*}$ : foreign monetary policy

III : domestic sterilized foreign exchange intervention

III $^{*}$ : foreign sterilized foreign exchange intervention

This classification is based on the types of assets that are being exchanged. Thus, when the authorities exchange domestic money $(M)$ for domestic bonds $(B)$, the transaction is referred to as domestic monetary policy (as in II), while when the authorities exchange domestic bonds $(B)$ for foreign bonds $\left(B^{*}\right)$, the transaction is referred to as domestic sterilized foreign exchange intervention (as in III). Some have characterized pure foreign exchange intervention as an exchange of domestic money $(M)$ for foreign money $\left(M^{*}\right)$ rather than the exchange of domestic money for foreign bonds. To complete the spectrum, this type of exchange is indicated in figure 5-5 by $\mathrm{I}^{\prime}$ and $\mathrm{I}^{\prime *}$, respectively.

This general classification highlights two principles. First, it shows that the differences between the various policies depend on the different characteristics of the various assets that are being exchanged. These different characteristics are at the foundation of the portfolio-balance model. Second, it shows that domestic and foreign variables enter symmetrically into the picture. Thus, for example, a given exchange between $M$ and $B^{*}$ can be effected through the policies of the home country or through a combination of policies of the foreign country. This symmetry suggests that there is room (and possibly a role) for international coordination of exchange rate policies. It also illustrates the " $(n-1)$ problem" of the international monetary system: in a world of $n$ currencies there are $(n-1)$ exchange rates and only $(n-1)$ monetary authorities need to intervene in order to attain a set of exchange rates. To ensure consistency, the international monetary system needs to 


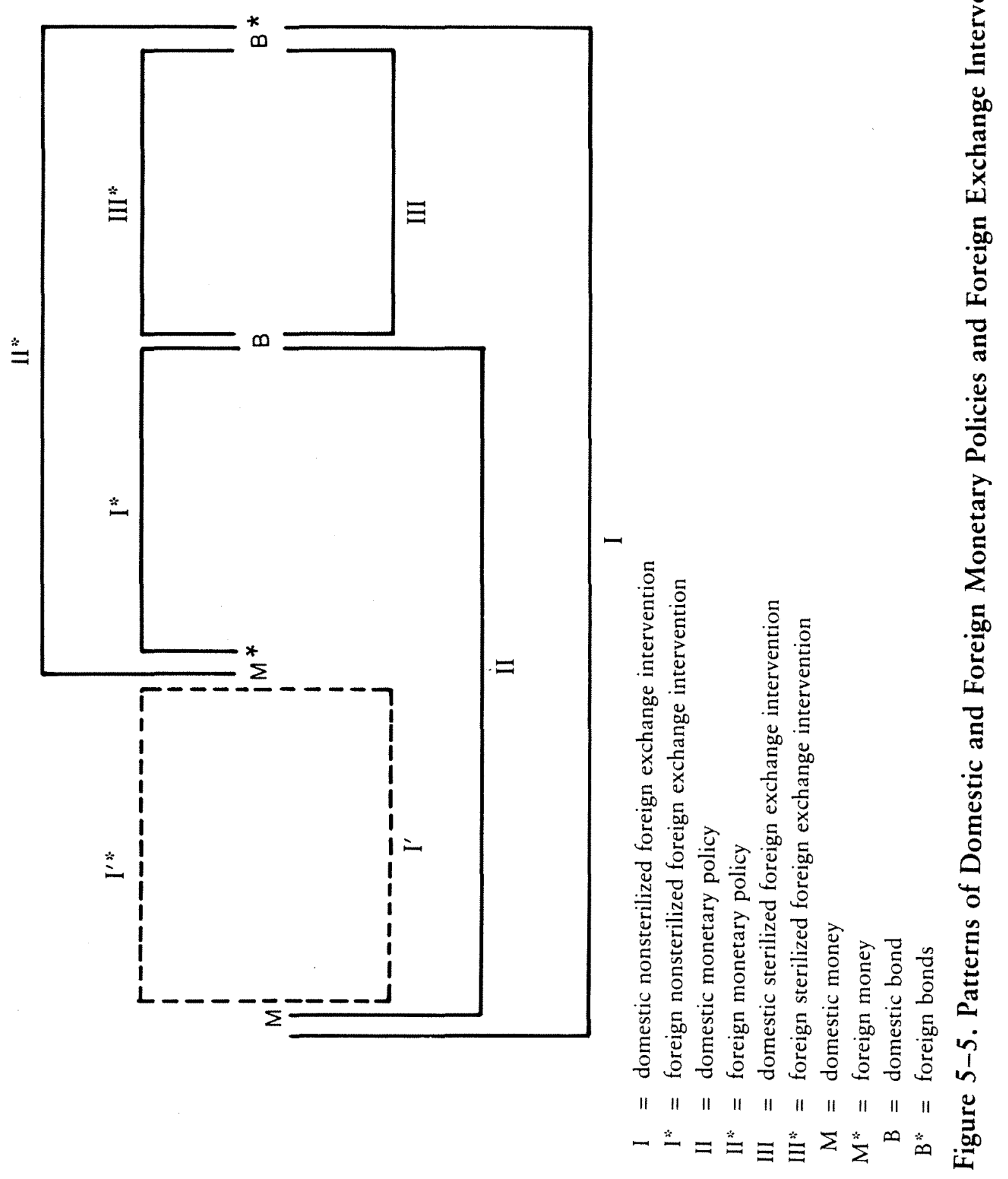


specify the allocation of the remaining degree of freedom (see Mundell, $1968)$. Thus, the ( $n-1)$ problem imposes an additional constraint on the conduct of macroeconomic policy in the interdependent world economy.?

\section{Some Policy Implications}

The foregoing analysis emphasized the constraints that are imposed on economic policy in the open economy. Under fixed exchange rates these constraints may be somewhat alleviated through sterilization policies, but the evidence sheds some doubts on the effectiveness of such attempts. As was also indicated, under flexible exchange rates the rapid changes in exchange rates also impose a constraint on the effectiveness of monetary policy in that they speed up the translation of monetary changes into changes in prices and wages. The recent volatility of nominal and real exchange rates, the slow pace of world economic recovery, and the strong dollar have been costly, have dangerously increased the popularity of protectionism, and also have resulted in an increased perception that exchange rate changes reduce the leverage of macro policy. Attempts to alleviate some of these constraints have given rise to various proposals concerning rules for intervention in the foreign exchange market. Some of these proposals are variants of a PPP rule according to which the authorities are expected to intervene so as to ensure that the path of the exchange rate conforms to the path of the relative price levels. These proposals, if effective, amount to guidelines for the conduct of monetary policy.

There are at least four difficulties with a PPP rule. First, there are intrinsic differences between the characteristics of exchange rates and the price of national outputs. These differences, which result from the much stronger dependence of exchange rates (and other asset prices) on expectations, suggest that the fact that exchange rates have moved more than the price level is not, in and of itself, sufficient evidence that exchange rate volatility has been excessive. Exchange rate volatility should be assessed by comparison with variability of prices of other assets such as securities. Viewed against this yardstick the evidence shows that the variability of exchange rates has been about half that of the stock market indexes. This, of course, does not mean that the volatility of either exchange rates or stock market indexes has been acceptable but rather that the degree of volatility may not be judged as being excessive just by pointing at the fact that exchange.rates have moved more than national price levels.

Second, the prices of national outputs do not adjust fully to shocks in the short run. Thus intervention in the foreign exchange market to ensure purchasing power parity would be a mistake. When commodity prices are slow to adjust to current and expected economic conditions, it may be desirable to allow for "excessive adjustment in some other prices. 
Third, there are continuous changes in real economic conditions that require adjustment in the equilibrium relative prices of different national outputs. Under these circumstances what seem to be divergences from purchasing power parities may really reflect equilibrating changes.

Fourth, if there is short-run stickiness of prices of domestic goods in terms of national monies, then rapid exchange rate adjustments, which are capable of changing the relative prices of different national outputs, are a desirable response to changing real economic conditions. An intervention rule rigidly linking changes in exchange rates to changes in domestic and foreign prices in accord with purchasing power parity ignores the occasional need for equilibrating changes in relative prices.

Now that I have outlined the key limitations of a policy that adopts a rigid PPP rule, what is left of the usefulness of the PPP doctrine? Its main usefulness is in providing a guide to the general trend of exchange rates, particularly in circumstances where the main shocks underlying the trend are of a monetary origin. As for the conduct of macroeconomic policy, it serves as an important reminder that the exchange rate and the price level cannot be divorced from each other and that policies affecting the trend of domestic (relative to foreign) prices are likely to affect the exchange rate in a similar manner.

Emphasis on the fact that exchange rates and prices are both endogenous variables is important in view of the recent allegations that flexible exchange rates were inflationary during the 1970s and have slowed down the recovery from the beginning of the 1980 s up to the time of this writing. Both exchange rates and prices respond to the same set of shocks and can be influenced by a similar set of policies. The fact that exchange rates adjust faster than commodity prices reflects the known phenomenon that asset markets clear relatively quickly. This fact does not imply that as an economic matter the chain of causality runs from exchange rates to prices.

Monetary policy can make a positive contribution to reducing costly and unnecessary fluctuations of exchange rates by reducing the variability of monetary expansion. This is especially important because exchange rates are affected not only by current policy actions, but also by expectations about future policy actions. If these expectations are highly sensitive to current policy, then instability of policies can have a magnified effect on the variability of nominal and real exchange rates. This variability can be reduced by adopting a stable and predictable pattern of government policy.

What should be the role of the exchange rate in the design of monetary policy? Generally, given that monetary and exchange rate policies should not be viewed as two independent instruments, consideration of the external value of the currency should play a relatively minor role in the design of monetary policy. The major consideration that should guide the monetary authority is that of achieving price stability.

While this prescription may seem to represent a revival of the "benign 
neglect" attitude, the opposite is the case. In the past, one of the major arguments for the benign neglect attitude in the United States was that the U.S. economy was relatively closed and the foreign trade sector was relatively unimportant. The typical statistic used to justify this position was the low share of imports in GNP. This argument was inappropriate in the past and is even less appropriate under present circumstances. The United States has always been an open economy. The relevant measure of openness to international trade in goods and services is not the share of actual trade in GNP but rather the share of tradable commodities in GNP (that is, potential trade), which is far larger than that of actual trade. Furthermore, as stated in the section Capital Mobility and the Constraints on Macroeconomic Policies, one of the main linkages of the United States to the world economy is operating through world capital markets into which the United States is clearly well integrated. The same principle applies to the measures of openness of most countries.

The prescription is based on the notions that the economy is open, that the external value of the currency is important, that the maintenance of price stability is an important policy goals, and that policy viewing the exchange rate as an independent target (or, even worse, as an independent instrument) is likely to result in unstable prices. Furthermore, if monetary policy succeeds in achieving price stability, it might be useful to allow for fluctuations of the exchange rate that provide for a partial insulation from misguided foreign monetary policies.

Even when monetary policy is not guided by exchange rate targets, it might attempt to offset disturbances arising from shifts in the demand for money. Such shifts in demand may be especially pronounced under a regime of flexible exchange rates. A policy that accommodates such demand shifts by offsetting supply shifts would reduce the need for costly adjustments of exchange rates and national price levels. The difficulty with implementing this policy is in identifying when a shift in money demand has occurred. Obviously, the nominal rate of interest is not a reliable indicator of money market conditions. The more relevant indicators are the components of the nominal rate of interest - the real rate of interest and the expected rate of inflationbut these components are unobservable.

Here the exchange rate may be useful as an indicator for monetary policy, especially when frequent changes in inflationary expectations make nominal interest rates an unreliable indicator of fluctuations in money demand. For example, as argued in Frenkel and Mussa $(1980,1981)$, a combination of a high nominal interest rate differential and a depreciation of the currency (a situation that prevailed in the United States during most of the 1970 s) indicates a rise in inflationary expectations that should not be fueled by an accommodative monetary policy. On the other hand, a combination of 
a high nominal interest rate differential and an appreciation of the currency (a situation that seems to have prevailed in the United States since the latter part of 1979) indicates a rise in the demand for money. Under such circumstances accommodation by an expansionary monetary policy may be desirable.

The foregoing discussion of the implications of policies on the exchange rate dealt with exchange rate volatility. But it is important to emphasize that the chief complaint against the operation of the present system of managed float is that exchange rates of major currencies have been subject to large and persistent misalignments. Such misalignments (especially an overvaluation of the real effective exchange rate of the U.S. dollar and an undervaluation of the Japanese yen) have been costly because they impact adversely on resource allocation, induce adjustment costs (including unemployment), distort optimal levels of capital formation, and encourage protectionism.

The apparent misalignment of the U.S. dollar resulted from a combination of macroeconomic policies in the United States and abroad. The tight stance of monetary policy during the disinflationary period of the early 1980 s, the loose fiscal stance in the United States, the contractionary fiscal positions in the United Kingdom, West Germany, and Japan, and the slow pace of economic recovery in Europe (relative to the United States) have all contributed to the drastic real appreciation of the U.S. dollar. It is important to identify these factors since unless they are dealt with seriously, it might be difficult to put a halt to the growing pressures for protectionism.

It is hard to recall another period in which sentiments for protection have been so widespread in the United States as they are at the present. An excessive emphasis on the U.S. budget deficit as the sole cause for the dollar's strength and the growing frustration with the efforts to reduce the U.S. fiscal deficit by conventional measures have brought about new desperate arguments for the adoption of protectionist measures like import surcharges. The danger with such recommendations is that they might receive the political support of two otherwise unrelated groups. They are likely to gain the support of the traditional advocates of protectionism who claim to defend local industry and workers from foreign unfair competition. But, more dangerously, they may gain the support of those whose exclusive concern with the budget deficit leads them to support almost any policy that raises fiscal revenue. Once in place, import surcharges (even those adopted as "temporary measures") are hard to remove since, as George Stigler once remarked, "a sustained policy that has real effects has many good friends." At the present there are very few measures whose long-term costs to the interdependent world economy may be as high as protectionist measures. Taxes on trade will hurt exports, and will restore inward-looking economic isolationism instead of outward-looking economic coordination. Protectionist measures will transmit the wrong signals to those developing countries that 
are still attempting to resist domestically popular pressures to default on their debt, and, further, they may ignite trade war. Therefore, one needs to resist the temptation to "solve" budgetary difficulties by means of import tariffs.

In view of the disruptive effects exerted by the strong and highly volatile dollar, and in view of the mounting pressures for protectionism and the apparent failure to restore fiscal soundness, various proposals for reform of the international monetary system have been put forward. Is this the time for reform? I believe not! If indeed an important cause for the current strength of the dollar lies in the fiscal positions of the United States, Europe, and Japan, then the solution for the problems does not call for a monetary reform. Nor does it call for tariffs and protectionism, for taxes on capital flows (or other measures that throw sand in the wheels), or for the adoption of mechanistic intervention rules. Rather, it calls for a restoration of fiscal order in which the United States adopts a more contractionary fiscal stance while Europe and Japan adopt a more expansionary stance. The central difficulties with the current regime do not rest with the exchange rate system per se or with the existing exchange rate policies; rather, they rest with the overall mix of the uncoordinated macroeconomic policies. It is unlikely, therefore, that the introduction of exchange rate targets or other superficial measures dealing only with the symptoms of the disease can do any good unless they are accompanied by drastic changes in the way in which macroeconomic policies are designed. Put differently, it makes no sense to agree just on real exchange rate targets without accompanying such an arrangement with a similar agreement about other targets for macroeconomic policies including, of course, fiscal policies. In fact, the adoption of policies that deal with anything but the ultimate root cause may do more harm than good. Indeed, placing excessive weight on the management of exchange rates may divert attention from the more central role that global macroeconomic policies play in the interdependent world economy.

\section{Notes}

1. Due to space limitation the chapter pays more attention to the role of monetary policy than to the role of fiscal policy. This should not be interpreted to argue that the open economy constraints on fiscal policy and the implications of international fiscal interdependence are of a lesser importance. For a discussion of the constraints on fiscal policies, see Frenkel and Mussa (1981). For an analysis of fiscal interdependence, see Frenkel and Razin (1986).

2. The analysis draws on Frenkel (1981).

3. This paragraph draws on Frenkel and Mussa (1981).

4. This analysis is based on Frenkel (1983b).

5. While these are the general characteristics of the adjustment process, the details of the precise path are somewhat more complicated since the expected transitional changes in the exchange rates will alter transitorily the rate of interest. Along 
the path between $E$ and $D$, the domestic currency appreciates and, if this appreciation is expected, the domestic rate of interest is below the world rate due to interest arbitrage. Therefore, during the transition period the desired ratio of money to equities will exceed the one described in figure 5-4, and the initial depreciation will be somewhat smaller than the one indicated by point $E$. The new equilibrium is reached at point $A$ when the exchange rate reaches its new level, and when the domestic and foreign rates of interest are equalized.

6. The importance of the degree of capitalization and marketability of claims to future income streams was analyzed in the context of a closed economy by Metzler (1951) and Mundell (1960). For an application to an economy under fixed exchange rates see Obstfeld (1982). (1968).

7. For an analysis of the various dimensions of interdependencies, see Cooper

\section{References}

Aizenman, Joshua, and Jacob A. Frenkel. "Optimal Wage Indexation, Foreign Exchange Intervention and Monetary Policy," American Economic Review 75, no. 3 (June 1985): 402-23.

Alexander, Sidney S. "Effects of a Devaluation on a Trade Balance." IMF Staff Papers 2 (April 1952): 263-78.

Allen, Polly R., and Peter B. Kenen. Asset Markets, Exchange Rates and Economic Integration. Cambridge, England: Cambridge University Press, 1980.

Branson, William H. "Assets Markets and Relative Prices in Exchange Rate Determination," Sozialwissenschaftliche Annalen 1 (1979): 69-89.

Cooper, Richard N. The Economy of Interdependence. New York: McGraw-Hill, 1968.

Dornbusch, Rudiger. "Real and Monetary Apsects of the Effects of Exchange Rate Changes" in R.Z. Aliber (ed.), National Monetary Policies and the International Financial System. Chicago: University of Chicago Press, 1974, pp. 64-81.

- Open Economy Macroeconomics. New York: Basic Books, 1980.

Fleming, J. Marcus. "Domestic Financial Policies under Fixed and under Flexible Exchange Rates." IMF Staff Papers 9 (1962): 369-79.

Frenkel, Jacob A. "Macroeconomic Policy in an Open Economy," Estudios Monetarios VII: Alternatives de Politicas Financieras en Economias Pequenas y Avientas al Exterior. Santiago: Director de Politica Financiera, Banco Central de Chile, 1981, pp. 53-97.

- "Monetary Policy: Domestic Targets and International Constraints," American Economic Review 73, no. 2 (May 1983a): 48-53.

-. "International Liquidity and Monetary Control" in George M. von Furstenberg (ed.), International Money and Credit: The Policy Roles. Washington, D.C.: International Monetary Fund, 1983b, pp. 65-109.

Frenkel, Jacob A., and Joshua Aizenman. "Aspects of the Optimal Management of Exchange Rates," Journal of International Economics 13 (November 1982): 231-56. 
Frenkel, Jacob A., and Michael L. Mussa. "The Efficiency of Foreign Exchange Markets and Measures of Turbulence," American Economic Review 70, no. 2 (May 1980): 374-81.

- "Monetary and Fiscal Policies in an Open Economy," American Economic Review 71, no. 2 (May 1981): 253-58.

- "Asset Markets, Exchange Rates and the Balance of Payments" in Ronald W. Jones and Peter B. Kenen (eds.), Handbook of International Economics, vol. II. Amsterdam: North-Holland and New York: Elsevier Science, 1985, pp. 679-747.

Frenkel, Jacob A., and Assaf Razin. "Fiscal Policies in the World Economy," Journal of Political Economy, forthcoming, 1986.

Henderson, Dale. "Modeling the Interdependence of National Money and Capital Markets," American Economic Review 67, no. 2 (May 1977): 190-99.

Johnson, Harry G. "Towards a General Theory of the Balance of Payments" in International Trade and Economic Growth. Cambridge, Mass.: Harvard University Press, 1958, pp. 153-68.

McKinnon, Ronald I., and W.E. Oates. "The Implications of International Economic Integration for Monetary, Fiscal and Exchange Rate Policy." Princeton Studies in International Finance, no. 16. Princeton, N.J.: Princeton University, 1966.

Meade, James E. The Theory of International Economic Policy, Vol. I: The Balance of Payments. London: Oxford University Press, 1951.

Metzler, Lloyd A. "Wealth, Savings and the Rate of Interest," Journal of Political Economy 59, no. 2 (April 1951): 93-166.

Mundell, Robert A. "The Public Debt, Corporate Income Taxes and the Rate of Interest," Journal of Political Economy 68, no. 2 (December 1960): 622-26.

- "The International Disequilibrium System," Kyklos 14, no. 2 (1961): $154-72$.

- "The Appropriate Use of Monetary and Fiscal Policy under Fixed Exchange Rates." IMF Staff Papers 9 (March 1962): 70-79.

- "Capital Mobility and Stabilization Policy under Fixed and Flexible Exchange Rates," Canadian Journal of Economic and Political Science 29 (November 1963): 475-85.

- International Economics. New York: Macmillan, 1968.

Mussa, Michael L. "The Exchange Rate, the Balance of Payments and Monetary and Fiscal Policy under a Regime of Controlled Floating," Scandinavian Journal of Economics 78, no. 2 (May 1976): 229-48.

- "Macroeconomic Interdependence and the Exchange Rate Regime" in Rudiger Dornbusch and Jacob A. Frenkel (eds.) International Economic Policy: Theory and Evidence. Baltimore: Johns Hopkins University Press, 1979, pp. 160-204.

- "The Role of Official Intervention." Occasional papers, no. 6. New York: Group of Thirty, 1981.

- "The Theory of Exchange Rate Determination," in John F.O. Bilson and Richard Marston (eds.), Exchange Rate Theory and Policy. Chicago: University of Chicago Press, 1984, pp. 13-78.

Obstfeld, Maurice. "The Capitalization of Income Streams and the Effects of OpenMarket Policy under Fixed Exchange Rates," Journal of Monetary Economics 9, no. 1 (January 1982): 87-98. 
- "Exchange Rates, Inflation and the Sterilization Problem: Germany, 19751981," European Economic Review 21, no. 1/2 (March-April 1983): 161-89.

Poole, William. "Optimal Choice of Monetary Instruments in a Simple Stochastic Macro-Model," Quarterly Journal of Economics 84 (May 1970): 197-216.

Swoboda, Alexander K. "Equilibrium, Quasi-Equilibrium, and Macroeconomic Policy under Fixed Exchange Rates," Quarterly Journal of Econmics 86, no. 1 (February 1972): 162-71.

Tinbergen, Jan. On the Theory of Economic Policy: Amsterdam: North-Holland, 1952.

Wallich, Henry C. "Exchange-Market Intervention: Issues and Views," Journal of Commerce (August 12-13, 1982). 